\title{
STRATEGI PEMBELAJARAN ANTI BIAS GENDER DI PAUD
}

Lutfatulatifah ${ }^{*}$

IAIN Syekh Nurjati Cirebon

\section{lutfatulatifah@syekhnurjati.ac.id}

\section{-Received: 12 April $\bullet$ Accepted: 26 Mei $\bullet$ Published online: 1 Juni 2021 2021 2021}

\begin{abstract}
:
Tujuan dari makalah ini adalah untuk menjelaskan bagaimana strategi pembelajaran anti bias gender di Lembaga pendidikan anak usia dini. Pembelajaran anti bias gender sendiri dimaksudkan untuk memperjuangkan kesetaraan yang bukan berarti mempertentangkan laki-laki dan perempuan tetapi upaya untuk membangun hubungan yang setara dan kesempatan yang sama bagi laki-laki dan perempuan. Dalam Makalah ini menggunakan pendekatan kajian literatur. Terdapat tiga tema besar yang dibahas dalam makalah ini. Yakni gender, strategi pembelajaran anti bias gender, dan peran. Dalam strategi pembelaajaran anti bias gender sendiri membahas terkait perencanaan, pembelajaran, dan evaluasi. Pembelajaran ini tentu memiliki tujuan untuk menciptakan kesetaraan dan keadilan gender yang tidak dapat hanya diusahakan oleh salah satu pihak saja. Tapi perlu kejasama antar semua komponen diantaranya yakni, sekolah, orangtua, peserta didik, pengelola dan juga masyarakat.
\end{abstract}

Kata kunci: anti bias, gender, pembelajaran, paud

\section{Abstract}

The purpose of this paper is to explain how the anti- gender biar learning strategy in early childhood education institutions. The anti gender bias learning ist self is intended to fight for equality which does not mean opposing men and women but an effort to build equal relationships and equal opportunities for men and women. This

\footnotetext{
*Corresponding Author, Email: Lutfatulatifah@syekhnurjati.ac.id
} 


\section{Lutfatulatifah}

paper uses a literature review approach. There are three major themes discussed in this paper. Namely gender, anti-gender biased learning strategies, and roles. The antigender bias learning strategy itself discusses planning, learning, and evaluation. This learning certainly has the aim of creating gender equality and justice which cannot only be pursued by one party. But there needs to be cooperation between all components including, schools, parents, students, managers and also the community.

Keywords: anti bias, gender, learning, early childhood education.

\section{A. PENDAHULUAN}

Konstruksi pendidikan di Indonesia belum secara tegas memberi porsi yang seimbang pada upaya penyetaraan gender. Meski kebijakan bidang pendidikan sesungguhnya telah mengalami perubahan pasca terbitnya Inpres No. 9 Tahun 2000 tentang Pengarusutamaan Gender dalam Pembangunan Nasional kemudian disusul terbitnya Undang-Undang Nomor 20 Tahun 2003 tentang Sistem Pendidikan Nasional. Namun dalam tataran praktiknya, masih terdapat kebijakan- kebijakan intenal di lembaga pendidikan yang belum responsif gender (Priatmoko, 2018).

Ada banyak beragam isu gender pada pendidikan anak usia dini. Salah satunya adalah isu gender dalam proses pembelajaran dan kegiatan bermain. Dimana pembelajaran pada pendidikan anak usia dini merupakan aktivitas dalam menerapkan nilai kesetaraan dan keadilan gender (kemendikbud, 2014). Isu-isu itu diantaranya yakni masih ditemukannya sterotipe dalam kegiatan bermain, dimana anak-anak perempuan dan laki-laki mempergunakan alat bermain yang menunjukkan dimensi segregarif, misalkan anak perempuan bermain barbie sedangkan laki-laki bermain mobil-mobilan (Adriany, 2019). 


\section{Lutfatulatifah}

Disamping itu buku-buku teks, buku cerita, atau bahan ajar yang dipergunakan oleh guru/tutor yang belum mencerminkan kesetaraan dan keadilan gender. Peran guru yang juga tidak seimbang akan anak laki-laki dan perempuan dalam kegiatan bermain. Selain itu guru rendahnya guru PAUD lakilaki juga membuat konstruksi peran guru TK yang timpang karena terlalu didominasi oleh guru perempuan (Maulana, Kurniati, Yulindrasari, 2020).

Konsep kesetaraan dan keadilan gender masih sangat terbatas di semua kalangan (Utaminingsih, 2017). Pendidikan anti bias gender dimaksudkan untuk memperjuangkan kesetaraan yang bukan berarti mempertentangkan dua jenis kelamin, laki-laki dan perempuan. Tetapi lebih kepada upaya membangun hubungan (relasi) yang setara dan kesempatan yang sama bagi laki-laki dan perempuan. Maka pendidikan yang berwawasan gender menjadi pilihan yang strategis. Agar terwujudnya satuan pendidikan anak usia dini yang responsive gender.

\section{B. METODOLOGI PENELITIAN}

Penelitian ini menggunakan kajian literatur atau library research,_yakni penelitian yang dilakukan dengan mengumpulkan data yang besifat kepustakaan, atau telaah yang dilaksanakan untuk memecahkan suatu masalah dengan bahan-bahan Pustaka yang relevan. Beberapa sumber bahan yang relavan itu diantaranya buku-buku teks, jurnal ilmiah, referensi statistic, hasilhasil penelitian dalam bentuk skripsi, tesis, desertasi, dan internet, serta sumbersumber lainnya (Sanusi, 2016). 


\section{Lutfatulatifah}

Penelitian ini bersifat deskripsi berfokus pada penjelasan sistematis tentang fakta yang diperoleh saat penelitian dilakukan (Sanusi, 2016). Dalam makalah ini Fakta tersebut berkaitan dengan bagaimana strategi pembelajaran anti bias gender di PAUD.

Penelitian dengan pendekatan kajian literatur ini tergolong pada penelitian kualitatif. Penelitian kualitatif merupakan jenis penelitian yang temuan-temuannya tidak diperoleh melalui prosedur statistic atau bentuk hitungan lainnya (Strauss \& Corbin, 2003).

\section{RESULT AND DISCUSSION}

Pada bagian ini setidaknya terdapat tiga tema besar dalam pembahasan. Pertama, Gender. Kedua, strategi impelementasi pembelajaran anti bias gender di PAUD. Ketiga, peran-peran dalam pembelajaran anti bias gender . Berikut penjelasan lebih lanjut :

a. Gender

Istilah gender digunakan untuk menjelaskan perbedaan laki-laki dan perempuan yang bersifat bawaan sebagai ciptaan Tuhan dan yang bersifat bentukan budaya yang dipelajari dan disosialisasikan sejak kecil (Puspitawati, 2013).

Gender adalah perbedaan antara laki-laki dan perempuan dalam peran, fungsi, hak, tanggung jawab, dan perilaku yang dibentuk oleh tata nilai sosial, budaya dan adat istiadat dari kelompok masyarakat yang dapat berubah menurut waktu serta kondisi setempat. Tanggung jawab dan perilaku yang dibentuk oleh tata nilai sosial, budaya dan adat istiadat dari 


\section{Lutfatulatifah}

kelompok masyarakat yang dapat berubah menurut waktu serta kondisi setempat. Dengan demikian gender menyangkut aturan sosial yang berkaitan dengan jenis kelamin manusia laki-laki dan perempuan. Perbedaan biologis dalam hal alat reproduksi antara laki-laki dan perempuan memang membawa konsekuensi fungsi reproduksi yang berbeda (perempuan mengalami menstruasi, hamil, melahirkan dan menyusui; laki-laki membuahi dengan spermatozoa). Jenis kelamin biologis inilah merupakan ciptaan Tuhan, bersifat kodrat, tidak dapat berubah, tidak dapat dipertukarkan dan berlaku sepanjang zaman.

b. Strategi impelementasi pembelajaran anti bias gender di PAUD

Dalam pembelajaran anti bias gender di PAUD setidaknya ada tiga hal yang perlu dipertimbangkan yakni, perencanaan, pelaksanaan, dan evaluasi.

1. Perencanaan

Pembelajaran anti bias gender pada Lembaga Pendidikan Anak Usia Dini membutuhkan komitmen dari semua pihak, yaitu pengelola, pendidik, tenaga kependidikan, dan orang tua (Lestari, 2019). Hal ini sejalan dengan apa yang di ungkapkan oleh Bronfenbrenner (Härkönen, 2001) terkait teori ekologi bahwa anak belajar dari lingkungan terdekatnya terlebih dahulu. Lingkungan terdekat anak adalah orangtua, sekolah dan masyarakat. Sehingga dalam perencanaan perlu ada komitmen Bersama, komitmen tersebut diwujudkan dalam bentuk:

a. Perlu dibuat kebijakan atau aturan di lembaga PAUD yang merespon keadilan dan kesetaraan gender dalam bentuk bentuk; 
anti diskriminasi gender, anti kekerasan, dan berbagai bentuk ketidakadilan lainnya (Nurhaeni, 2011). Menyusun dokumen pengembangan lembaga yang merespon terhadap aspirasi dan kebutuhan laki-laki dan perempuan. Kebijkan dan dokumen pengembangan ini menjadi dasar dan acuan akan ketentuan untuk menyetarakan gender. Aturan ini tidka hanya menyentuh pada peserta didik namun juga orangtua juga pengelolah Lembaga pendidikan anak usia dini.

b. Terdapatnya sumber daya yang memiliki pemahaman yang baik tentang gender dan pengarusutamaan gender (gender focal point) yang dapat menjadi sumber belajar bagi semua komponen yang terlibat dalam pendidikan di satuan pendidikan (Ahmad, 2019).

c. Melakukan analisis terhadap kebijakan/aturan yang selama ini telah dilakukan dalam perspektif keadilan dan kesetaraan gender.

Dalam tahap perencanaan sosialisasi menjadi penting. Sosialisasi dimaksudkan untuk menyebarluaskan informasi, kebijakan, dan aturan terhadap para pihak yang terlibat dalam penyelenggaraan pendidikan anak usia dini, yaitu; pendidik, tenaga kependidikan, orang tua, dan masyarakat sekitar lembaga PAUD. Beberapa informasi yang perlu disampaikan dalam sosialisasi tersebut di antaranya adalah: 
a. Pentingnya memperlakukan anak secara setara dan adil di semua lingkungan kehidupan anak, mulai dari keluarga, sekolah, dan lingkungan masyarakat.

b. Perilaku-perilaku yang perlu dihindari sebagai bentuk diskriminasi gender, misalnya; pelabean negatif, subordinasi, marginalsiasi, beban ganda, dan kekerasan.

c. Program kerja sekolah yang mendorong terwujudkan keadilan dan kesetaraan gender.

\section{Pelaksanaan}

Pembelajaran gender pada satuan pendidikan anak usia dini akan terwujud manakala komitmen yang telah dibuat pihak yang terlibat dalam menyelenggaraan pendidikan anak usia dini dilaksanakan dengan baik. Hal yang diperlukan untuk mengawal pelaksanaan integrasi gender di satuan pendidikan anak usia dini adalah:

a) Memastikan bahwa kebijakan/aturan yang dihasilkan oleh satuan pendidikan anak usia dini memberikan respon yang adil dan setara gender.

b) Memastikan bahwa semua pihak yang terlibat dalam penyelenggaraan pendidikan anak usia dini di satuan pendidikan mengintegrasikan dimensi keadilan dan kesetaraan gender dalam setiap aktivitasnya.

c) Memastikan bahwa sarana dan prasarana yang dimiliki oleh satuan pendidikan anak usia dini memberikan manfaat 
terhadap pengembangan aspek-aspek perkembangan anak, baik anak perempuan maupun laki-laki.

\section{Evaluasi}

Integrasi dimensi keadilan dan kesetaraan gender pada satuan pendidikan anak usia dini dapat berhasil manakala dilakukan dengan penuh korektif, artinya pihak-pihak yang terlibat melakukan evaluasi dan perbaikan terhadap apa yang telah dilakukannya. Beberapa pertanyaan yang perlu diperhatikan sebagai upaya untuk memperbaiki integrasi dimensi keadilan dan kesetaraan gender, di antaranya:

a. Apakah semua komponen yang terlibat dalam penyelenggaraan pendidikan anak usia dini, termasuk di dalamnya orang tua masih tetap memiliki komitmen untuk mengintegrasikan dimensi keadilan dan kesetaraan gender di satuan PAUD?

b. Apakah kebijakan/aturan yang responsif yang telah disusun selama ini efektif untuk mendorong terwujudnya keadilan dan kesetaraan gender di satuan pendidikan anak usia dini?

c. Apa kendala (internal atau eksternal) yang dihadapi dalam mengintegrasikan dimensi keadilan dan kesetaraan gender pada satuan pendidikan anak usia dini?

d. Apakah yang dapat dilakukan untuk menyelesaikan kendala pengintegrasian dimensi keadilan dan kesetaraan gender pada satuan pendidikan anak usia dini? 
d) Peran

Dalam pembahasan peran ini yakni membahas siapa sajakah yang berperan dan menjadi komponen satuan pendidikan dalam menciptakan budaya anti bias gender.

1. Pendidik
a. Memberikan keteladanan yang keadilan sosial;
b. Menerapkan pembelajaran keadilan gender;
c. Memberikan penilaian yang tidak diskriminatif;
d. Membangun relasi dengan semua anak yang tidak diskriminatif

2. Pengelola
a. Memberi keteladanan keadilan social
b. Melakukan kebijakan yang berkeadilan social
c. Menegakkan peraturan tanpa diskriminasi
d. Mengembangkan relasi warga sekolah yang berkeadilan social

3. Peserta Didik
a. Berperilaku tidak melecehkan ras, etnis, gender, budaya, bahasa, keterbatasan atau agama tertentu.
b. Mematuhi kebijakan sekolah yang berkeadilan social
c. Menempatkan diri sesuai dengan posisinya.
d. Hubungan sosial setara sesama teman tanpa diskriminasi. 
4. Tenaga Kependidikan
a. Memberi keteladanan yang berkeadilan social
b. Memberikan pelayanan tanpa diskriminasi
c. Melaksanakan pekerjaan tanpa stereotype dan tidak memihak
d. Menjalankan peraturan tanpa diskriminasi
e. Menerapkan keadilan sosial di lingkungan kerjanya
f. Mendukung kebijakan sekolah yang berorientasi kesetaraan dan keadilan sosial

\section{Orangtua}
a. Memberi keteladanan dalam kesetaraan dan keadilan sosial
b. Mendorong lahirnya kebijakan Keadilan sosial
c. Membiasakan pemberian akses, peran pengambilan keputusan atau kontrol yang sama antar antar anak.
d. Mendorong terwujudnya partisipasi kelompok marjinal dalam kegiatan sekolah

\section{CONCLUSION}

Anak belajar dari lingkungan terdekatnya. Orangtua dan sekolah memiliki peran yang sangat penting dalam pembelajaran anti bias gender pada anak. Konsep gender terbentuk dari budaya dan lingkungan social. Jika lingkungan sekitar anak tidak memahami gender maka yang tebentuk adalah tindakan-tindakan yang tidak adil secara gender. Sehingga perlu pemahaman 


\section{Lutfatulatifah}

kesetaraan gender pada anak usia dini menjadi Langkah penting dalam pembelajaran anti bias gender.

Dalam strategi pembelajaran anti bias gender sendiri ada tiga tahapan diantanya yakni perencanaan, pelaksanaan, dan evaluasi. Masing-masing orang dewasa di sekitar anak juga memiliki peran dalam membentuk konsep gender. 


\section{REFERENCES}

Adriany, V. (2019). 'I don't want to play with the Barbie boy': Understanding Gender-Based Bullying in a Kindergarten in Indonesia. International journal of bullying prevention, 1(4), 246-254.

Achmad, S. (2019). Membangun pendidikan berwawasan gender. Yinyang: Jurnal Studi Islam Gender Dan Anak, 14(1), 70-91.

Härkönen, U. (2001). The Bronfenbrenner ecological systems theory of human development.

Lestari, N. G. A. M. Y. (2019). Program Parenting Untuk Menumbuhkan Kesadaran Pentingnya Keterlibatan Orang Tua Di Paud. Pratama Widya: Jurnal Pendidikan Anak Usia Dini, 4(1), 8-17.

MacNaughton, G. (2000). Rethinking gender in early childhood education. Sage.

Maulana, R. A., Kurniati, E., \& Yulindrasari, H. (2020). APA YANG MENYEBABKAN RENDAHNYA KEBERADAAN GURU LAKI-LAKI DI PAUD?. Jurnal Ilmiah Visi, 15(1), 23-32.

Nurhaeni, I. D. A. (2011). Reformasi kebijakan pendidikan menuju kesetaraan dan keadilan gender.

Sanusi, A. (2016). Metodologi Penelitian Bisnis. Jakarta: Salemba Empat.

Strauss, A., \& Corbin, J. (2003). Penelitian Kualitatif. Yogyakarta: Pustaka Pelajar.

Utaminingsih, A. (2017). Gender dan wanita karir. Universitas Brawijaya Press.

Puspitawati, H. (2013). Konsep, teori dan analisis gender. Bogor: Departe-men Ilmu Keluarga dan Kon-sumen Fakultas Ekologi Manusia Institut Pertanian. 


\section{Lutfatulatifah}

Priatmoko, S. (2018, February). Strategi implementasi pembelajaran inklusif gender di madrasah ibtida'iyah. In PROCEEDING: The Annual International Conference on Islamic Education (Vol. 3, No. 1, pp. 244-257). 